\title{
The Effectiveness Of Internal And External Mechanisms Of Corporate Control
}

Joanne P. Healy, (E-mail: jhealy@bsa3.kent.edu), Kent State University

\begin{abstract}
This research reflects a recent trend toward the development of an overall understanding of corporate control. Previous research has examined CEO turnover and corporate takeovers separately. This research provides a more complete analysis of the corporate control of the firm conditioned on previous events over the period 1978 - 1988. Logistic regression analyses indicate that the probability of a takeover offer is highest for firms performing poorly which have not previously replaced their CEO. Debt, the percentages of stock held by the ceo or outside investor, and the existence of an antitakeover mechanism also affect the probability of a firm receiving a takeover offer. Results support the theory that external corporate control mechanisms do function when internal mechanisms have failed to function. Additionally, results suggest the external labor market is working to attract the CEO of a firm performing well.
\end{abstract}

\section{Introduction}

The purpose of this research is to empirically test whether external corporate control mechanisms function when internal corporate control mechanisms have failed. Typically, in a publicly owned corporation the owners are not the managers. Stockholders form a board of directors who in turn hire managers to run the corporation. This separation of ownership and control leads to the possibility of a divergence in interests between the managers and the owners, which is called an agency problem.

both internal and external forces may limit agency problems in a public corporation [fama (1980); fama and jensen (1983b); jensen (1984), (1986)]. Internal forces include management competition for positions, and the board of directors' rights to hire and fire top management and to set their compensation. Large blockholders may also serve as external monitors through proxy fights and lawsuits [Shleifer and Vishny (1986)]. Externally, the labor and takeover markets may also play this role. When internal control mechanisms fail to discipline the chief executive officer (CEO), external control mechanisms should take over [Fama (1980); Fama and Jensen (1983b); Jensen (1984), (1986)].

Researchers have tended to study CEO turnovers and takeovers as if they are separate phenomena. ${ }^{1}$ Fama (1980), Fama and Jensen (1983a, 1983b), Walsh and Seward (1990), Hirshleifer and Thakor (1994), and John and Senbet (1998) Suggest that there are interrelationships between and among the corporate control mechanisms. We know relatively little about the role the external takeover market plays for firms where internal corporate governance mechanisms have been ineffective. This research is designed to provide a more complete analysis of the corporate control of the firm conditioned on previous events over the time period $1978-1988$. This paper empirically tests the relationship between CEO turnover and corporate takeover attempts. This paper expands our understanding of the discipline hypothesis. Under the discipline hypothesis firms

Readers with comments or questions are encouraged to contact author via email.

\footnotetext{
${ }^{1}$ See Furtado and Karan (1990) and Pavlik et al (1993) for a review of selected empirical studies of the causes, consequences, and market effects of management turnover.
} 
that are performing poorly, but have not replaced their CEO could be a target for an external corporate control change. Previous researchers in this area have drawn their samples from firms receiving takeover bids. These studies fail to identify firms that require monitoring. Since firms performing well may also receive hostile bids and poor performers may receive friendly or no bids, these studies could contain both type i and type ii errors. This current research identifies firms needing discipline based on previous firm performance by starting with a sample of firms and by following those firms over a ten year period, or until they are taken over. Discipline is conditioned on firm performance. CEOS that have performed poorly are expected to be disciplined first through internal corporate control mechanisms. Ultimately, if the $\mathrm{CEO}$ has not been replaced, it is expected that the firm will receive a takeover offer.

Results indicate that the probability of a takeover offer is highest for firms performing poorly which have not previously replaced their CEO. Debt, the percentages of stock held by the CEO or outside investor, and the existence of an antitakeover mechanism also affect the probability of a firm receiving a takeover offer. Results support the theories that external corporate control mechanisms do function when internal mechanisms have failed to function. Additionally, results suggest that poorly performing firms which have not replaced their CEO are more likely to receive a hostile takeover offer than a friendly offer.

The remainder of this paper is organized as follows. Section 2 presents overviews of internal and external monitoring mechanisms. Hypotheses are presented in section 3. Section 4 presents the data, variable specification, and research design to test the hypotheses presented. Results are presented in section 5. Concluding remarks are presented in section 6 .

\section{Overview}

The separation of ownership and control in public corporations leads to a divergence of motivations between the owners and executives [Fama (1980); Jensen and Meckling (1976)]. Stockholders elect a board of directors whose role it is to establish a reward/incentive system to induce the executives to pursue stockholders' interests. One role of the board of directors is to provide incentives for the CEO, which align the interests of the CEO and the shareholders. The board can provide incentives for managers either through compensation packages or ultimately dismissal.

In his seminal article, Manne (1965) discuses how the market for corporate control influences the corporation. Manne makes control of the firm's management an "entrepreneurial job" which falls first to the firm's organizers and later to the takeover market.

Alchian and Demsetz (1972) and Jensen and Meckling (1976) view the firm as a "set of contracts". Alchian and Demsetz examine the monitoring of management by inside and outside markets for managers. They assign the monitoring task primarily to the shareholders, the managerial labor markets, and the possibility of outside takeover.

Jensen and Meckling (1976) expand the Alchian and Demsetz's set of contracts' to include contracts among all factors of production. Monitoring is accomplished because of contractual relations with employees, customers, suppliers, creditors, etc.

Fama (1980) explained how the separation of ownership and control can be an efficient form of economic organization. Competition from other firms force stockholders to efficiently monitor the performance of the firm's managers. Managers face both discipline for poor performance and opportunities in the labor market for good performance both within and outside the firm. Within the firm internal monitoring of managers by other managers takes place. Lower level managers could move ahead by replacing poorly performing upper management. Other members of the firm's management serving on the board have an incentive to monitor the CEO. Their value to the managerial labor market is in part determined by the firm's performance.

Fama and Jensen (1983b) summarize several mechanisms for controlling the agency problems of 
specialized risk bearing. The board of directors plays the role of the internal monitor. The board delegates most decision-making authority to top-level managers. The stock market is an external monitoring devise that reflects the implications of managers' decisions on current and future cash flows. Fama and Jensen state that this form of external monitoring exerts pressure on the manager to make decisions in the best interests of the residual claimants. The market for takeovers provides a form of external monitoring as a last resort.

Jensen (1986) argues that the external takeover market functions to protect shareholders when the corporation's internal controls are "slow, clumsy, or defunct". Jensen states that takeovers usually occur when a major restructuring of the firm is necessary. New management teams recognize the opportunity to realize gains from reorganization and redeployment of the assets. Hostile takeovers are an effective way for shareholders to get rid of non-value-maximizing managers [Jensen and Ruback (1983), Jarrell et al. (1988)].

\section{Hypotheses development}

The first step in investigating the role of accounting performance in the control decision is to identify, within the context of the CEO turnover decision, which firms are likely to be considered poor performers. The first hypothesis deals with the proposition that there is a relation between firm performance and CEO turnover. ${ }^{2}$ This research examines the probability that a $\mathrm{CEO}$ will be replaced during a given year conditioned on firm performance.

\section{Hypothesis n1: firm performance does not affect CEO turnover.}

Hypothesis a1: poorly performing firms are more likely to dismiss their CEO than firms performing well.

If internal control mechanisms fail to discipline the CEO, external control mechanisms should take over [Fama (1980)]. Under this theory, when the firm's performance is suboptimal, other management teams are likely to offer themselves as alternatives for the right to manage the firm's resources. ${ }^{3}$ This research examines the probability that a firm will receive a takeover offer conditioned on firm performance.

Hypothesis n2: firm performance is not related to a corporate takeover offer.

Hypothesis a2: poorly performing firms are more likely to receive a takeover offer than a firm performing well.

The disciplinary theory of takeovers posits that the external takeover market provides discipline when internal governance mechanisms have been ineffective. If this theory is accurate, it is expected that the probability of a takeover offer will be higher for firms performing poorly which have not replaced their CEO. ${ }^{4}$ A supportive test of

\footnotetext{
${ }^{2}$ Several studies document the relation between firm performance and the probability of a change in management. Examples include McEachern (1975); James and Soref (1981); Benston (1985); Couglan and Schmidt (1985); Warner, Watts, and Wruck (1988); Weisbach (1988); Jensen and Murphy (1990); Gibbons and Murphy (1990); Barro and Barro (1990); and Puffer and Weintrop (1991).

${ }^{3}$ Palepu (1986) found that excess stock returns averaged over four years had a significant negative coefficient indicating that poorly performing firms were more likely to be acquired. Morck et al. (1989) found a relation between performance measured in three ways, Tobin's Q, stock market returns, and employment growth rates, and the probability of a hostile takeover attempt. Shivdasani (1993) found a negative but insignificant relation between hostile takeovers and change in earnings before interest and taxes. Kini et L. 19995) found a significant inverse relationship between pre-takeover performance and subsequent CEO turnover for targets with insider- dominated boards of directors.
}

\footnotetext{
${ }^{4}$ Morck et al. (1989) examined the effectiveness of the board of directors in disciplining top management. Their approach differs from this current research in that it divides the sample into firms that have a complete change in top management, one in which the list of officers signing the annual letter to the shareholders changes completely between 1980 and 1985, hostile and acquisitions. They found that the probability of a complete change in management increase when a firm significantly underperforms its industry. For their groups classified as friendly and hostile, performance is a significant determinant of acquisition. Martin and McConnell 91991) reported that within 3 years of takeover, 61 percent of the managers of target firms leave after a successful takeover compared to 21 percent of the mangers of other companies. Shivdasani (1993) also examined whether boards of directors and hostile takeovers are alternative governance mechanism. Shivdasani's current research. He defines firms needing discipline as firms receiving hostile bids. He classified a bid as being hostile if the initial bid was rejected or not acknowledged by the board. This current research identifies firms needing discipline based on previous firm performance. Definition of firms needing discipline differs from this
} 
this theory is to examine whether the interaction between previous firm performance and turnover is related to subsequent takeover offers. This research examines the probability that the firm will receive a takeover offer conditioned on previous firm performance and previous CEO turnover.

Hypothesis n3: for poorly performing firms, CEO turnover is not related to subsequent takeover attempts.

Hypothesis a3: poorly performing firms are more likely to receive a takeover attempt if they have not previously replaced their $C E O$.

\section{Entrenchment}

CEO's are aware of their situation. Faced with the possibility of dismissal, it is expected that the CEO works to ensure his/her job. Stock ownership by the CEO or outside blockholder or a strong board of directors can be important influences on firm performance [Morck, Shleifer, and Vishny (1988)] and voting patterns [Deangelo (1988); Mukherjee and Varela (1993)]. A higher proportion of stock owned or controlled by the CEO increases the cost of dismissal to the board or of takeover [Stulz (1988) and Shivdasani (1993)]. Inside directors' jobs could also be linked to the success of the CEO and thus internal monitoring may be more effective when the board is controlled by outside directors [Weisbach (1988) and Shivdasani (1993)]. An alternative view is that inside directors are more aware of the performance of the CEO and will remove an inefficient CEO more often than outside directors so that they can take his place. The debt/equity ratio can also influence a firm's attractiveness as a takeover target [Palepu (1986)]. The interrelationship among firm characteristics, stock ownership, and firm performance and their effect on corporate governance is not well understood [Jensen and Warner (1988)].

When the board has failed to discipline a firm's managers for poor performance, the potential benefits of a takeover are high. At the same time an ineffective board allows the firm's managers to create mechanisms which increase the costs of a takeover for the bidder. The effectiveness of takeover as a disciplinary mechanism then depends on these two countervailing forces. Managers can attempt to entrench themselves to subvert a hostile takeover. Defensive entrenchment strategies raise the cost of takeovers [Shleifer and Vishny (1989)]. This research allows for the effect of several entrenchment mechanisms on the turnover/takeover relationship and examines the relation among characteristics of the firm, the CEO, and the board of directors and the likelihood of a takeover attempt.

\section{Sample and methodology}

\section{(i) Sample Selection}

The sample is all the firms with sic codes between 2000 - 3999 that are listed on COMPUSTAT and CRSP for which proxy statements were available. The study is limited to manufacturing firms because of interindustry differences in firm characteristics such as physical asset requirements, inventories, debt structures, and regulatory environments [Ely (1991)]. The articles in The Wall Street Journal relating to the departures of all CEO's were read to identify reasons for the departure. In most cases, the article did not give a reason. Therefore, to control for the possibility that the CEO left because of normal retirement, CEO's 64 and over are eliminated. There are 337 firms with 2932 firm years available based on these criteria.

\section{(ii) Data selection}

The name of each CEO for each year 1977 - 1988 was obtained. The intent of this study was to follow the same companies over a ten-year period. The announcements in The Wall Street Journal Index for each of the companies in the sample were read for the period 1978 - 1988 to identify takeover attempts. 


\section{(iii) Performance Measurement}

Previous accounting research has focused on the use of accounting and stock price performance measures in compensation contracts [Lambert and Larcker (1987) and Sloan (1993)]. The empirical work in this research requires a performance variable to proxy for the measure of performance used in corporate control decisions. In the absence of a theory to predict which performance variable is used by the board of directors in the corporate control decision, several measures of performance were examined. Since similar results were obtained using return on assets, sales growth, change in earnings per share, and stock returns, only results using a firm's adjusted stock returns are presented in this paper. ${ }^{5}$

(iv) Methodology

(a) Test of Hypothesis 1

model:

The implicit relation between firm performance and CEO turnover was examined using the following logit

TURN $_{\mathrm{it}}=\mathrm{A}_{\mathrm{i}}+\beta_{\mathrm{i}}^{*} \mathrm{ADJRET}_{\mathrm{it}-1}+\mathrm{E}_{\mathrm{it}-1}, \mathrm{~T}=1978-1988$

Where,

TURN $_{\mathrm{it}}=1$ if the CEO leaves the firm, 0 otherwise.

$\mathrm{ADJRET}_{\mathrm{it}-1}=$ the adjusted stock return for the previous year.

(b) Test of Hypothesis 2

Logit analysis was used to test the hypothesis that the probability of a takeover offer is higher for poorly performing firms than for other firms using the following model:

TAKEOVER $_{\mathrm{it}}=\mathrm{A}_{\mathrm{i}}+\beta_{\mathrm{i}}{ }^{*}$ ADJRET $_{\mathrm{it}-1}+\mathrm{E}_{\mathrm{it}-1}, \mathrm{~T}=1978-1988$,

Where,

TAKEOVER $_{\text {it }}=1$ if there is a takeover offer for firm i during period $t, 0$ otherwise.

$\mathrm{ADJRET}_{\mathrm{it}-1}=$ the adjusted stock return for the previous year.

This research defines a takeover offer to be an attempt to change the corporate control of the firm. Corporate control is the right to manage a firm's resources. A change in corporate control through takeover can be accomplished either through a proxy contest, merger, or tender offer. This research does not distinguish between the three approaches.

\section{(c) Multivariate Tests - Test of Hypothesis 3}

What is of primary interest in this study is whether takeover offers are conditioned on firm performance and CEO turnover. It is possible that neither firm performance nor CEO turnover alone affects the probability of a takeover offer but instead it is the interaction of the two that measures the extent of external discipline. In this study it is expected that the probability of a takeover offer will be higher for firms performing poorly which have not replaced the CEO. Therefore the interaction between firm performance and CEO turnover is included as an

\footnotetext{
${ }^{5}$ Adjusted stock returns are calculated as the firm's annual stock return less the market return.
} 
independent variable.

When the board has failed to discipline a firm's managers for poor performance, the potential benefits of a takeover are high. At the same time, an ineffective board allows the firm's managers to create mechanisms which increase the costs of a takeover for the bidder. The effectiveness of takeover as a disciplinary mechanism then depends on these two countervailing forces. Managers can attempt to entrench themselves to subvert a hostile takeover. Defensive entrenchment strategies raise the cost of takeovers [Shleifer and Vishny (1989)]. This research examines the relation among characteristics of the firm, the CEO and the board of directors and the likelihood of a takeover attempt using the following logit model:

TAKEOVER $_{\text {it }}=A_{i}+\beta_{1}$ TURN $_{\text {it- } 1}+\beta_{2}$ ADJRET $_{\text {it }-1}+\beta_{3}$ INTER $_{\text {it }-1}+\beta_{4}$ ISIZE $_{\text {it }-1}+\beta_{5}$ IDEBT $_{\text {it- } 1}+\beta_{6}$ STOCK $_{\text {it- } 1}+$ $\beta_{7} \mathrm{ANTI}_{\mathrm{it}-1}+\beta_{8} \mathrm{INSIDE}_{\mathrm{it}-1}+\beta_{9} \mathrm{BLOCK}_{\mathrm{it}-1}+\mathrm{E}_{\mathrm{it}}, \quad \mathrm{T}=1978-1988$

Where,

TAKEOVER $_{\text {it }}=1$ if there is a takeover offer for firm i during period t, 0 otherwise.

Tuen $_{\text {it-1 }}=0$ if the CEO was replaced within the previous year, 1 otherwise.

ADJRET $_{\text {it-1 }}=$ a firm's adjusted stock return.

INTER $_{\text {it-1 }}=$ TURN $_{\text {it-1 }} *$ ADJRET $_{\text {it-1 }}$

LSIZE $_{\mathrm{it}-1}=$ the natural $\log$ of the total assets of firm $\mathrm{i}$ at the end of period $\mathrm{t}-1$.

LDEBT $_{\text {it-1 }}=$ the natural log of the ratio of long-term debt to tangible assets for firm $\mathrm{i}$ at the end of period $\mathrm{t}-1$.

STOCK $_{\mathrm{it}-1}=$ the percentage of stock beneficially owned by the CEO of firm $\mathrm{i}$ at the end of period $\mathrm{t}-1$.

$\mathrm{ANTI}_{\mathrm{it}-1}=1$ if the firm has an antitakeover mechanism in place at the end of period $\mathrm{t}-1,0$ otherwise.

$\mathrm{INSIDE}_{\mathrm{it}-1}=$ the ratio of inside directors to total directors for firm $\mathrm{i}$ at the end of period $\mathrm{t}-1$.

BLOCK $_{\mathrm{it}-1}=$ percentage of stock beneficially owned by the largest outside blockholder at the end of period $\mathrm{t}-1$.

\section{Predictions regarding the independent variables}

TURN is a dummy variable equal to 0 if the CEO changed during the previous year and 1 otherwise to allow us to interpret the interactive variable. We expect that firms will be more likely to receive a takeover offer if they have not replaced their CEO in the previous year given poor performance, therefore $\beta_{1}$ is predicted to be positive.

The extent of which measures of firm performance act as proxies for stockholders' perceptions of CEO performance is an empirical question. Unexpected changes in firm performance could signal the degree of the CEO's effectiveness. Stock returns represent a proxy for CEO performance. If the external corporate control market functions to discipline firms performing poorly, it is predicted that $\beta_{2}$ will be negative.

It is possible that performance and CEO turnover interact to influence takeover. It is expected that the takeover market will evaluate firm performance to determine whether performance is the result of management or

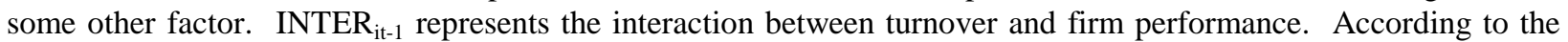
discipline hypothesis, poorly performing firms which have not replaced their CEO in the previous year are more likely to receive a takeover offer. It is predicted that $\beta_{3}$ will be negative.

Since it could be more costly to take over a large firm, it is expected that larger firms are less likely to receive a takeover offer [Morck et al. (1989) and Shivdasani (1993)]. $\beta_{4}$ is expected to be negative.

The higher the debt to tangible assets ratio the less likely the firm will receive a takeover offer because the increased debt lowers the bidder's gain from control. Shleifer and Vishny (1989) point out that it is possible that Debt has been issued containing covenants that require full payment if the firm is acquired. It is expected that as debt (debt) increases, the probability that firms receive a takeover offer will decrease [Palepu (1986)]. It is predicted 
that $ß_{5}$ will be negative.

Large stockholdings by the CEO make it more difficult and costly for the company to be taken over. Stock represents the percentage of the firm's stock beneficially owned by the CEO. An increase in the percentage of stock owned by the CEO can make a takeover offer less likely. It is predicted that $\beta_{6}$ will be negative.

ANTI is a dummy variable based on whether a company has an antitakeover mechanism in place at the end of the previous year. Because such mechanisms increase the cost of a takeover, $\beta_{7}$ is expected to be negative.

INSIDE represents the proportion of inside directors to total directors on the firm's board. Inside directors face the possibility of dismissal in the event of a takeover. Increases in the proportion of inside directors could lower the probability of a takeover [Weisbach (1988) and Shivdasani (1993)]. It is predicted that $\beta_{8}$ will be negative.

The more dispersed the stock ownership, the more difficult it is for enough stock to be purchased for control to be gained. The existence of a large blockholder makes it possible for a large block of stock to be purchased at once. The greater the proportion of stock owned by an outside blockholder, the higher the probability of a takeover offer [Shivdasani (1993)]. However, if the large blockholder is unwilling to sell, a large blockholding could increase the cost of a takeover. Therefore the predicted sign of $\beta_{9}$ is uncertain.

\section{Results}

(i) Firm Performance and CEO Turnover, Tests of Hypothesis 1

Table 1 reports the results of logit regressions between firm performance and CEOrnover. The firms were ranked by performance and divided into thirds. Results are presented for the lowest, middle, and highest thirds.

Table 1

Relations between firm performance and the probability of CEO turnover. Only changes for CEO's under 64 are included for sic codes 2000-3999. P-values in parentheses.

\begin{tabular}{lccc}
\hline & & Performance Level & \\
& $($ Low $)$ & (Mid) & (High) \\
\hline INTERCEPT- & 3.26 & -2.96 & $(0.0001)$ \\
ADJRET -1.28 & $(0.001)$ & $(0.0001)$ & $(0.034)$ \\
& -0.21 & 0.91 & 3.797 \\
Chi-square & $(0.069)$ & $(0.862)$ & $(0.0513)$ \\
P-value & 3.071 & 0.030 & 931 \\
Observations & $(0.0797)$ & $(0.862)$ &
\end{tabular}

TURN equals 1 if the CEO changed during the current year, 0 otherwise. ADJRET is the firm's prior year's adjusted stock return.

The performance coefficient (ADJRET) is $-1.28(\mathrm{p}=0.069)$ for the poor performers and $0.91(\mathrm{p}=0.034)$ for the high performance group. When firm performance is poor, the probability of a CEO turnover increases as Firm performance decreases. However, as performance increases for the high performing firms the probability of a CEO turnover increases. These results are interesting and extend previous research since performance is insignificant for the middle group. Internal control mechanisms do function to discipline CEO's of poorly performing firms [Benston (1985), Coughlan and Schmidt (1985), Warner et al. (1988)]. At the same time, the external labor market appears to function for CEO's of firms performing well. 
Tests of hypothesis 2 and hypothesis 2.

Hypothesis A2, poorly performing firms are more likely to receive a takeover attempt than a firm performing well was tested using equation (2). Hypothesis a3, poorly performing firms are more likely to receive takeover offer if they have not previously replaced their CEO is tested using equation (3). Both models were estimated in two ways: first using prior year adjusted stock returns for all firms, and second using a measure of trend in market adjusted stock returns. Results are presented in table 2.

Table 2

Logit regressions of the likelihood of a takeover attempt using ownership, firm, and governance characteristics. $\mathrm{P}$-values are in parentheses.

\begin{tabular}{|c|c|c|c|c|c|c|c|c|c|c|c|}
\hline & INTERCEPT & T TURN & ADJRET & INTER & LSIZE & LDEBT & STOCK & ANTI & INSIDE B & BLOCK & Chi-square \\
\hline \multicolumn{12}{|c|}{ Panel a: performance is adjusted stock returns (2832 observation) } \\
\hline Model 1 & $\begin{array}{l}-2.70 \\
(0.001)\end{array}$ & & $\begin{array}{l}-0.79 \\
(0.001)\end{array}$ & & & & & & & & $(0.0008)$ \\
\hline Model 2 & $\begin{array}{l}-2.80 \\
(0.001)\end{array}$ & $\begin{array}{l}0.75 \\
(0.001)\end{array}$ & $\begin{array}{l}-0.76 \\
(0.002)\end{array}$ & & & & & & & 23.033 & $(0.0001)$ \\
\hline Model 3 & $\begin{array}{c}1.77 \\
(0.139)\end{array}$ & & & $\begin{array}{l}-0.668 \\
(0.014)\end{array}$ & $\begin{array}{l}-0.30 \\
(0.001)\end{array}$ & $\begin{array}{l}1.17 \\
(0.009)\end{array}$ & $\begin{array}{l}-4.98 \\
(0.015)\end{array}$ & $\begin{array}{l}-0.47 \\
(0.014)\end{array}$ & $\begin{array}{l}-0.90 \\
(0.127)\end{array}$ & $\begin{array}{c}6.56 \\
(0.001)\end{array}$ & $\begin{array}{l}122.549 \\
\quad(0.0001)\end{array}$ \\
\hline \multicolumn{12}{|c|}{ Panel b: performance is measured as the trend in adjusted stock returns (287 observations) } \\
\hline Model 1 & $\begin{array}{l}-0.86 \\
(0.001)\end{array}$ & & $\begin{array}{r}-4.87 \\
(0.030)\end{array}$ & & & & & & & & $\begin{array}{c}4.857 \\
(0.0275)\end{array}$ \\
\hline Model 2 & $\begin{array}{l}-1.27 \\
(0.001)\end{array}$ & $\begin{array}{c}0.52 \\
(0.125)\end{array}$ & $\begin{array}{l}-4.67 \\
(0.036)\end{array}$ & & & & & & & & $\begin{array}{c}7.293 \\
(0.0261)\end{array}$ \\
\hline Model 3 & $\begin{array}{l}-1.43 \\
(0.426)\end{array}$ & & & $\begin{array}{l}-4.91 \\
(0.043)\end{array}$ & $\begin{array}{l}0.10 \\
(0.383)\end{array}$ & $\begin{array}{l}1.34 \\
(0.053)\end{array}$ & $\begin{array}{l}-2.95 \\
(0.188)\end{array}$ & $\begin{array}{l}-2.31 \\
(0.001)\end{array}$ & $\begin{array}{l}-0.53 \\
(0.657)\end{array}$ & $\begin{array}{l}7.66 \\
(0.001)\end{array}$ & $\begin{array}{l}81.913 \\
(0.0001)\end{array}$ \\
\hline
\end{tabular}

TAKEOVER equals 1 if there is a takeover attempt of the firm during the period in panel a, turn equals 0 if the CEO leaves during the previous year, 1 otherwise. In panel $b$, turn equals 0 if the CEO leaves during the last three years, 1 otherwise. ADJRET is the firm's prior year's adjusted stock return. LSIZE is the natural log of total assets. LDEBT is the natural log of the ratio of long-term debt to tangible assets. Stock denotes the percentage of stock beneficially owned by the CEO. Anti is 1 if the firm has an antitakeover mechanism in place. Inside is the ratio of inside directors to total directors. Block is the percentage of stock beneficially owned by the largest.

\section{Prior year adjusted stock returns}

Results measuring performance as adjusted stock returns are presented in table 2, panel a. The coefficient of the performance variable is -0.79 and -0.76 in models 1 and 2 and statistically significant with the sign as expected. The coefficient for turn is 0.75 , also significant with the expected sign. The coefficient for inter is -0.67 and significant supporting rejection of the third hypothesis. The coefficients of LSIZE, LDEBT, stock, anti, and block are all statistically significant. Larger firm size, a higher proportion of stock ownership by the CEO and the presence of an antitakeover mechanism appear to reduce the probability of a takeover offer. Higher levels of debt and a higher percentage of stock ownership by an outside investor increase the probability of a takeover offer. 


\section{Trend in the market adjusted stock return}

It is unclear how long it takes for external control to take place. It is also possible that stock prices increase prior to a takeover offer because investors are anticipating the offer. To allow for these possibilities the model is reestimated using a trend of ten years in the firm's market adjusted annual stock return. The trend is obtained by regressing the adjusted return over ten years and using the slope of the line as a measure of trend for each variable. The intent is to obtain one observation for each company. Turn is now equal to 0 if the CEO was replaced in any of the three previous years, 1 otherwise. Three years were arbitrarily selected to allow time for the internal control mechanism to function the new CEO to improve firm performance. A CEO turnover more than three years ago could be unrelated to a current takeover offer.

Results are reported in table 2, panel b. The coefficient of ADJRET is -4.87 and -4.67 and is statistically significant in models 1, 2. When ADJRET and turn are replaced with inter in model 3 , inter is significant and negative as expected providing further support for the rejection of null hypothesis 3 . Anti is negative and LDEBT and block are positive and significant. LSIZE, stock, and inside are all insignificant. The higher the percentage of stock owned by one outside stockholder the more likely the firm will receive a takeover offer. Overall, it appears that poorly performing firms which have not replaced their CEO are more likely to receive a takeover offer.

(iii) Further Tests of Hypothesis

\section{(a) Actual Probability of TAKEOVER Offers}

Actual probabilities were calculated for the lowest 20th percentile, highest 20th percentile, and middle 60th percentile of firms. Results are present in table 3. About sixty percent of the firms in the lowest performance group received takeover offers compared to 36.2 percent of the firms in the highest performance group. For firms which have not replaced their CEO in the previous three years, the percentage of firms receiving a takeover offer is 60.9, 22.3, and 38.8 for the lowest, middle, and highest groups respectively. Seventy-six (81.7 percent) of all the takeover offers were received by firms with no CEO change in the previous three years. 


\section{Table 3}

Actual percentages of CEO turnover and corporate takeover offers by 20th percentiles based on trends in the annual market-adjusted stock returns. Time period $1978-1988$.

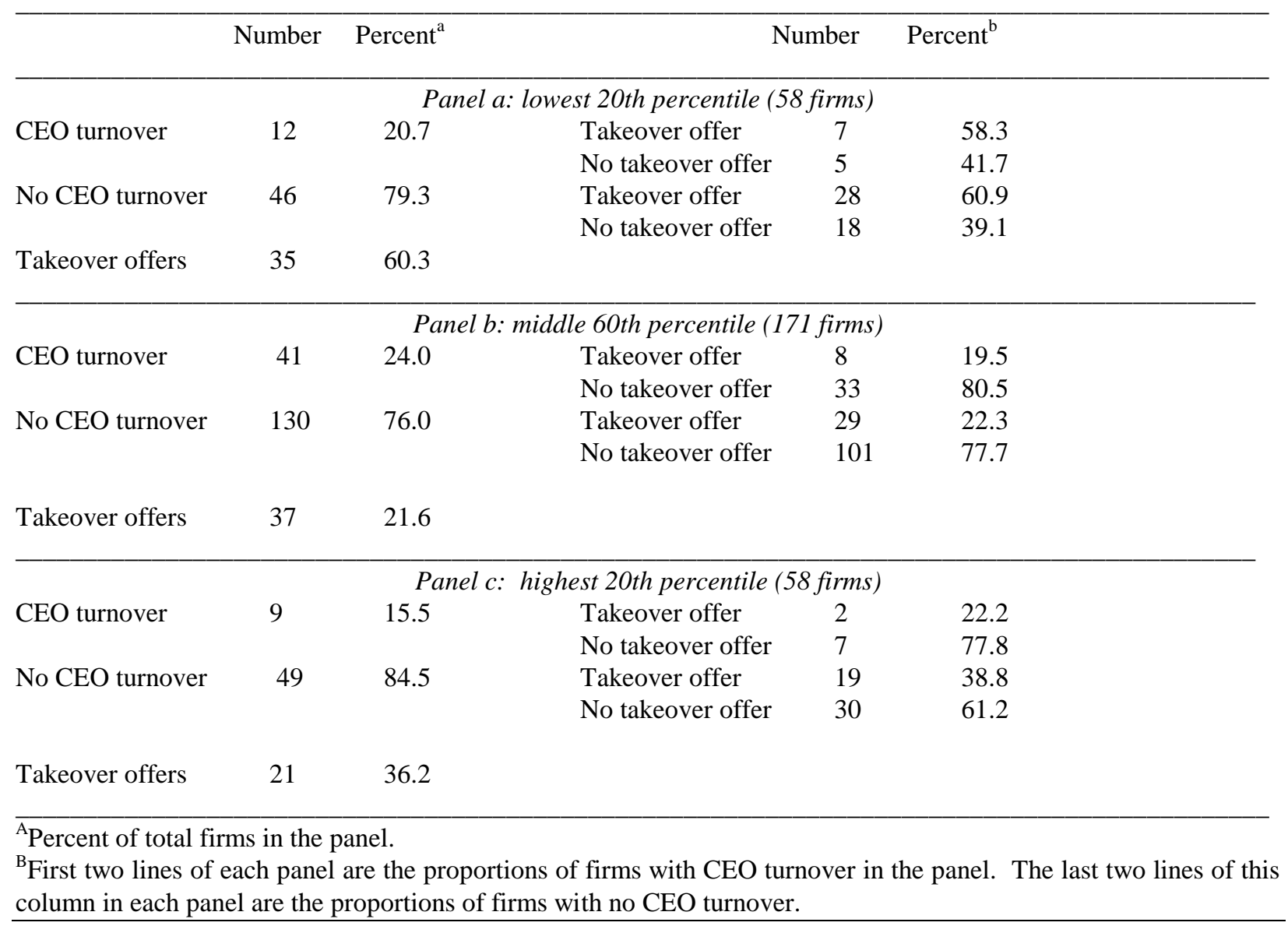

(b) Implied Probability of Takeover Offers

Logit regression coefficients are converted into estimated takeover offer probabilities. ${ }^{6}$ Results are presented in table 4 . The probabilities of a takeover offer are $0.409,0.316$, and 0.259 for the lowest, middle, and highest groups respectively. The t-statistic for the difference in the means of the lowest and highest groups is 15.22 , significant at 1 percent. There are also significant differences in the means of the lowest and middle groups ( $\mathrm{t}$-value is 11.05) and between the highest and middle groups ( $\mathrm{t}$-value is 9.82). ${ }^{7}$ Results suggest that there is a higher probability of a takeover offer for firms with very low performance than other firms. The highest probability of a takeover offer is obtained for the lowest performance group which have not replaced their CEO (0.424). The probability of a takeover offer is the lowest for firms when performance is very high and the CEO has been replaced

${ }^{6}$ Probabilities were calculated as $\mathrm{p}=\mathrm{e}^{\mathrm{x}} /\left(1+\mathrm{e}^{\mathrm{x}}\right)$, where $\mathrm{x}=-1.27+0.52 *$ TURN $-4.67 *$ ADJRET .

${ }^{7}$ These results are not separately reported in the Table. 
(0.216). Results are consistent with the theory that external corporate control mechanisms function when internal mechanisms have failed.

(iv) Stationarity

The sensitivity of the results to potential violations of the stationarity assumption was examined. Eleven logit regressions were run including a dummy variable for each year which is set to unity for one of the eleven years examined and 0 for the other ten years. The stationarity assumption does not appear to be violated for this sample of firms over this time period and results are not reported.

\section{Table 4}

Implied Probability ${ }^{\mathrm{a}}$ of corporate takeover offers by 20th percentiles of annual market-adjusted stock returns. Standard deviations are in parenthesis. Time period 1978 - 1988, sample 287 firms.

\begin{tabular}{|c|c|c|}
\hline & $\begin{array}{l}\text { Number } \\
\text { Of firms }\end{array}$ & $\begin{array}{l}\text { implied } \\
\text { probability }\end{array}$ \\
\hline \multicolumn{3}{|c|}{ Panel a: lowest 20th percentile (58 firms) } \\
\hline Total number of takeover offers & 35 & $\begin{array}{l}0.409 \\
(0.0607)\end{array}$ \\
\hline $\begin{array}{l}\text { Number of takeover offers for firms which have replaced } \\
\text { the CEO during the previous three years }\end{array}$ & 7 & $\begin{array}{l}0.354 \\
(0.0642)\end{array}$ \\
\hline $\begin{array}{l}\text { Number of takeover offers for firms which have no } 28 \\
\text { replaced the CEO during the previous three years } \\
\text { T-test } \\
\text { P-value }\end{array}$ & & $\begin{array}{l}0.424 \\
(0.0496) \\
4.025 \\
(0.0002)\end{array}$ \\
\hline \multicolumn{3}{|c|}{ Panel b: middle 60th percentile (171 firms) } \\
\hline Total number of takeover offers & 37 & $\begin{array}{l}0.316 \\
(0.0360)\end{array}$ \\
\hline $\begin{array}{l}\text { Number of takeover offers for firms which have replaced } \\
\text { the CEO during the previous three years }\end{array}$ & $\begin{array}{l}8 \\
(0.0154)\end{array}$ & 0.262 \\
\hline $\begin{array}{l}\text { Number of takeover offers for firms which have not } 29 \\
\text { replaced the CEO during the previous three years } \\
\text { T-test } \\
\text { P-value }\end{array}$ & 0.333 & $\begin{array}{l}(0.0207) \\
23.373 \\
(0.0001)\end{array}$ \\
\hline \multicolumn{3}{|c|}{ Panel c: highest 20th percentile (58 firms) } \\
\hline Total number of takeover offers & 21 & $\begin{array}{c}0.259 \\
(0.0444)\end{array}$ \\
\hline $\begin{array}{l}\text { Number of takeover offers for firms which have replace } \\
\text { the CEO during the previous three years }\end{array}$ & 2 & $\begin{array}{l}0.216 \\
(0.0203)\end{array}$ \\
\hline $\begin{array}{l}\text { Number of takeover offers for firms which have not } \\
\text { replaced the CEO during the previous three years } \\
\text { T-test } \\
\text { P-value }\end{array}$ & 19 & $\begin{array}{l}0.267 \\
(0.0432) \\
5.506 \\
(0.0001)\end{array}$ \\
\hline
\end{tabular}

${ }^{\mathrm{A}}$ Calculated as $\mathrm{p}=\mathrm{e}^{\mathrm{x}} /\left(1+\mathrm{e}^{\mathrm{x}}\right)$, where $\mathrm{x}=-1.27+0.52 *($ turn $)-4.67 *($ ADJRET $)$

Turn equals 1 if the CEO changed in the previous 3 years, 0 otherwise, and ADJRET is the trend in the market-adjusted stock returns of the firm. 
(iv) Friendly vs. Hostile takeovers

Morck et al. (1989) and Shivdasani (1993) draw their samples from firms receiving takeover bids. Since not all takeover bids are disciplinary, we classify takeover offers as either hostile or friendly. Offers were classified as friendly if the offer was solicited by management or management made no attempt to prevent the takeover.

\section{Table 5}

Relations among firm performance, CEO turnover, and the probability of a takeover attempt using logit regression analysis. Takeovers are classified as friendly or hostile.

Sic codes 2000 - 3999. (P-values are in parentheses). 1861 observations.

\begin{tabular}{|c|c|c|}
\hline & $\begin{array}{l}1=\text { hostile } \\
0=\text { other firms }\end{array}$ & $\begin{array}{l}1=\text { friendly } \\
0=\text { other firms }\end{array}$ \\
\hline INTERCEPT & $\begin{array}{c}0.52 \\
(0.841)\end{array}$ & $\begin{array}{l}-3.66 \\
(0.411)\end{array}$ \\
\hline INTER & $\begin{array}{l}-0.95 \\
(0.016)\end{array}$ & $\begin{array}{l}-0.44 \\
(0.535)\end{array}$ \\
\hline LSIZE & $\begin{array}{l}-0.31 \\
(0.019)\end{array}$ & $\begin{array}{l}-0.20 \\
(0.395)\end{array}$ \\
\hline LDEBT & $\begin{array}{l}1.66 \\
(0.003)\end{array}$ & $\begin{array}{l}-0.28 \\
(0.881)\end{array}$ \\
\hline STOCK & $\begin{array}{l}-8.94 \\
(0.073)\end{array}$ & $\begin{array}{l}-1.51 \\
(0.565)\end{array}$ \\
\hline ANTI & $\begin{array}{l}-0.35 \\
(0.192)\end{array}$ & $\begin{array}{l}-1.01 \\
(0.111)\end{array}$ \\
\hline INSIDE & $\begin{array}{l}-2.56 \\
(0.002)\end{array}$ & $\begin{array}{c}1.20 \\
(0.413)\end{array}$ \\
\hline BLOCK & $\begin{array}{l}6.40 \\
0.001)\end{array}$ & $\begin{array}{l}4.93 \\
(0.006)\end{array}$ \\
\hline TENURE & $\begin{array}{l}-0.22 \\
(0.154)\end{array}$ & $\begin{array}{l}-0.004 \\
(0.990)\end{array}$ \\
\hline AGE & $\begin{array}{l}0.46 \\
(0.320)\end{array}$ & $\begin{array}{c}0.42 \\
(0.581)\end{array}$ \\
\hline $\begin{array}{l}\text { Chi-square } \\
\text { P-value }\end{array}$ & $\begin{array}{l}102.109 \\
(0.0001)\end{array}$ & $\begin{array}{l}18.028 \\
(0.0348)\end{array}$ \\
\hline
\end{tabular}

Inter $=$ turn $*$ ADJRET. Turn equals 0 if the CEO leaves during the period, 1 otherwise. ADJRET is the firm's prior year's adjusted stock return. LSIZE is the natural log of total assets. LDEBT is the natural log of the ratio of long-term debt to tangible assets. Stock is the percent of stock beneficially owned by the CEO. Anti is 1 if the firm has an antitakeover mechanism in place. Inside is the ratio of inside directors to total directors. Block is the percentage of stock beneficially owned by the largest outside stockholder. Tenure is the natural log of the number of years the CEO has been employed by the firm. Age is the natural log of the CEO's age.

The first column of table 5 shows the results using hostile takeovers only against all other firms. For the firms receiving hostile bids, LSIZE and inside are significant and negative. Larger firms and firms with a high proportion of outsiders on their board are less likely to receive a hostile takeover offer. LDEBT and block are positive and significant. As the CEO stock ownership (stock) increases, the probability of a hostile takeover offer decreases. Both the amount of debt and the amount of stock held by a large outside blockholder (block) increase the probability of a hostile takeover offer. The only significant coefficient for the friendly takeover offers is for block. 
For both friendly and hostile takeover offers the existence of a large blockholder increases the probability of a takeover offer. It is interesting that the coefficient for inter is negative and significant for only the hostile takeover offers. It appears that poorly performing firms which have not replaced their CEO are more likely to receive a hostile takeover offer, however, the relationship is not significant for the friendly takeover offers.

\section{Summary and conclusions}

The theory of corporate control has received much widespread discussion, however little has been done empirically to completely examine the corporate control of a firm. This current research looks at the relation between firm performance, CEO turnover, and takeover attempts to provide an overall understanding of the corporate control of a firm. The research question addressed here is whether firms performing poorly which do not dismiss their CEO have a higher probability of receiving a takeover offer than firms performing well.

Results suggest a significant negative relation between the probability of CEO turnover and firm performance consistent with previous research. When we extend previous studies by dividing the sample into performance groups, the relation remains negative for the lowest performance groups. However, it is interesting that for the group with the highest performance there is a higher probability of a CEO turnover as performance increases. It appears an efficient managerial labor market can work to attract the CEO of a firm performing well. At the same time, poorly performing firms dismiss their CEO.

The probability a firm will receive a takeover offer was examined. As firm performance decreases, the probability of a takeover offer increases. Higher debt and large percentages of stock held by outside investors increase the probability of a takeover offer. Stock ownership by the CEO and the existence of an antitakeover mechanism reduce the probability of a takeover offer. Firms that have not previously replaced their CEO are more likely to receive a takeover offer.

Finally, results support the theory that external corporate control mechanisms will function when internal mechanisms have failed. Firms performing poorly which have not replaced the CEO have a higher probability of receiving a takeover offer than firms performing well. Additionally, when takeover offers are classified as hostile or friendly, we find that the poorly performing firms without CEO changes are more likely to receive a hostile offer, however, the relationship does not hold for friendly takeover offers. 


\section{References}

1. Alchian, a. A., and h. Demsetz, (1972), 'Production Information Costs, And Economic Organization', American Economic Review 62 (dec.), pp. 777-795.

2. Barro, j. R., and r. J. Barro, (1990), 'Pay, Performance, And Turnover Of Bank Ceo's', Journal Of Labor Economics (Oct.), pp. 448-481.

3. Benston, g. J., (1985), 'The Self-Serving Management Hypothesis: Some Evidence', Journal Of Accounting And Economics 7 (April), Pp. 67-84.

4. Coughlan, a. T., and r. M. Schmidt, (1985), 'Executive Compensation, Management Turnover, And Firm Performance, An Empirical Investigation', Journal Of Accounting And Economics 7 (April). Pp. 43-66.

5. Deangelo, 1. E., (1988), 'Managerial Competition, Information Costs, And Corporate Governance: The Use Of Accounting Performance Measures In Proxy Contests', Journal Of Accounting And Economics 10 (Jan.), Pp. 3-36.

6. Ely, K. M., (1991), 'Interindustry Differences In The Relation Between Compensation And Firm Performance Variables', Journal Of Accounting Research 29 (Sept.), Pp. 37-58.

7. Fama, E. F., (1980), 'Agency Problems And The Theory Of The Firm', Journal Of Political Economy 88 (April), Pp. 288-307.

8. Fama, E. F., And M. C. Jensen, (1983a), 'Agency Problems And Residual Claims', Journal Of Law And Economics 26 (June), Pp. 327-349.

9. Fama, E. F., And M. C. Jensen, (1983b), 'Separation Of Ownership And Control', Journal Of Law And Economics 26 (June), Pp. 301-325.

10. Furtado, E. P. H., And V. Karan, (1990), 'Causes, Consequences, And Shareholder Wealth Effects Of Management Turnover: A Review Of The Empirical Evidence', Financial Management (Summer), Pp. 6075.

11. Gibbons, R., And K. J. Murphy, (1990), 'Relative Performance Evaluation For Chief Executive Officers', Industrial And Labor Relations Review 43 (Feb.) Pp. 30-51.

12. Hirshleifer, D., And A. V. Thakor, (1994), 'Managerial Performance, Boards Of Directors And Takeover Bidding', Journal Of Corporate Finance 1, Pp. 63-90.

13. James, D. R., And M. Soref, (1981), 'Profit Constraints On Managerial Autonomy: Managerial Theory And The Unmaking Of The Corporation President', American Sociological Review 46 (Feb.), Pp. 1-18.

14. Jarrell, G. A., J. A. Brickley, And J. M. Netter, (1988), 'The Market For Corporate Control: The Empirical Evidence Since 1980', Journal Of Economic Perspectives 2 (Winter), Pp. 49-68.

15. Jensen, M. C., (1984), 'Takeovers: Folklore And Science', Harvard Business Review (Dec.), Pp. 109-121.

16. _ (1986), 'The Takeover Controversy, Analysis And Evidence', Midland Corporate Finance Journal 4, Pp. 6-32.

17. _ _ And W. H. Meckling, (1976), `Theory Of The Firm: Managerial Behavior, Agency Costs And Ownership Structure', Journal Of Financial Economics 3 (Oct.), Pp. 305-360.

18. _ _ _ And K. Murphy, (1990), 'Performance Pay And Top-Management Incentives', Journal Of Political Economy 98 ((April), Pp. 225-264.

19. _ _ And R. S. Ruback, (1983), 'The Market For Corporate Control The Scientific Evidence', Journal Of Financial Economics 11 (April), Pp. 5-50.

20. _ _ And J. B. Warner, (1988), 'The Distribution Of Power Among Corporate Managers, Shareholders, And Directors', Journal Of Financial Economics 20, Pp. 3-24.

21. John, K., And L. W. Senbet, (1998), 'Corporate Governance And Board Effectiveness', Journal Of Banking And Finance 22 (May), Pp. 371-403.

22. Kini, O., W. Kracaw, And S. Mian, (1995), Corporate Takeover, Firm Performance, And Board Composition', Journal Of Corporate Finance 1, Pp. 383-412.

23. Lambert, R., And D. Larcker, (1987), 'An Analysis Of The Use Of Accounting And Market Measures Of Performance In Executive Compensation Contracts', Journal Of Accounting Research 25 (Supplement), Pp. 85-129. 
24. Manne, H., (1965), 'Mergers And The Market For Corporate Control', Journal Of Political Economy 72, Pp. 110- 120.

25. Martin, K. J., And J. J. Mcconnell, (1991), 'Corporate Performance, Corporate Takeovers, And Management Turnover', Journal Of Finance 46 (June), Pp. 671-687.

26. Mceachern, W. A., (1975), Managerial Control And Performance, Lexington, Ma: D.C. Heath \& Co.

27. Morck, R., A. Shleifer, And R. W. Vishny, (1988), `Management Ownership And Market Valuation: An Empirical Analysis', Journal Of Financial Economics 20 (Jan/March), Pp. 293-315.

28. _ (1989), 'Alternative Mechanisms For Corporate Control', American Economic Review 79 (Sept.), Pp. 842-852.

29. Mukherjee, T. K., And O. Varela, (1993), 'Corporate Operating Performance Around Proxy Contests', Journal Of Business Finance And Accounting 20 (April), Pp. 417-425.

30. Palepu, K. G., (1986), 'Predicting Takeover Targets: A Methodological And Empirical Analysis', Journal Of Accounting And Economics 8 (March), Pp. 3-37.

31. Pavlik, E. L., T. W. Scott, And P. Tiessen, (1993), 'Executive Compensation: Issues And Research', Journal Of Accounting Literature 12, Pp. 131-189.

32. Puffer, S. M., And J. B. Weintrop, (1991), Corporate Performance And CEO Turnover: The Role Of Performance Expectations', Administrative Science Quarterly 36 (March), Pp. 1-19.

33. Shivdasani, A., (1993), Board Composition, Ownership Structure, And Hostile Takeovers', Journal Of Accounting And Economics 16 (Jan/Apr/July), Pp. 167-198.

34. Shleifer, A., And R. W. Vishny, (1986), 'Large Stockholders And Corporate Control', Journal Of Political Economy 94 (June), Pp. 461-488.

35. Shleifer, A., And R. W. Vishny, (1989), 'Management Entrenchment: The Case Of Manager-Specific Investment', Journal Of Financial Economics 25 (Nov.), Pp. 123-140.

36. Sloan, R. G., (1993), 'Accounting Earnings And Top Executive Compensation', Journal Of Accounting And Economics 16 (Jan/Apr/July), Pp. 55-100.

37. Stulz, R. M., (1988), 'Managerial Control Of Voting Rights, Financing Policies And The Market For Corporate Control', Journal Of Financial Economics 20 (Jan.), Pp. 25-54.

38. Walsh, J. P., And J. K. Seward, (1990), 'On The Efficiency Of Internal And External Corporate Control Mechanisms', Academy Of Management Review 15, Pp. 421-458.

39. Warner, J. B., R. L. Watts, And K. H. Wruck, (1988), 'Stock Prices And Top Management Changes', Journal Of Financial Economics 20 (Jan/Mar), Pp. 461-492.

40. Weisbach, M S., (1988), 'Outside Directors And CEO Turnover', Journal Of Financial Economics 20 (Jan/Mar), Pp. 431-460. 
Notes 